\title{
ECOLOGICAL IMPLICATIONS OF ALLOMETRIC GROWTH IN BRACHYURANS: DATA FROM UCA TANGERI RESIDENT IN A WEST AFRICAN MANGROVE SWAMP
}

I. EWA-OBOHO AND N. ABBY-KALIO

(Received 5, May 2009; Revision Accepted 20, October 2009)

\begin{abstract}
A survey was carried out on the fiddler crabs present in a small naturally defined mangrove swamp in the upper Bonny Estuary of the Niger Delta (S. Nigeria), the purpose of which was to study the ecological significance of the claws of the Ocypodidae crab, Uca tangeri (Eydoux, 1835).

Previous studies on the size of the claws of crabs generally have focused on their use in foraging. In the present investigation, the use of claws in reproduction provides further support to the view that evolution of crab chelae (claws) is not driven by feeding requirement alone. Mating pairs collected in the field showed that $>75 \%$ of mating males had chelae above the average size of the male population as a whole. Maintenance costs for cheliped in Uca tangeri estimated by respirometry were not significantly different from other body tissues as oxygen uptake could be predicted solely from dry tissue weight. Moreover, the rate of oxygen uptake was independent of the proportion of the total body weight that could be contributed by the chelipeds. Changes in the allometry of various dimensions at sexual maturity was observed in $U$. tangeri and suggests a sexual role in the crab.
\end{abstract}

\section{KEYWORDS: Relative growth, Uca tangeri; Claw size, Bonny Esturary.}

\section{INTRODUCTION}

The brachyuran features extensively in relative growth studies (Cott, 1922; Huxley, 1931; Teissier, 1960; Herreid, 1987; Hartnoll, 1995). In general, crustaceans have proved particularly useful for the study of relative growth for the following reasons: their hard integument facilitate accurate measurement, the intermittent ecdysial growth enables clear subdivision of ontogeny, and there are frequently differences in growth rates between males and females, and between mature and immature specimens. Brachyuran cheliped (claw) usually displays the phenomenon of relative growth and also comprises a large percentage of total body weight (Stein, 1976; Lee and Seed, 1992). Besides, its size with respect to overall body dimensions is rather large in many species (Vermeijj, 1977). Many workers (Hamilton, et al., 1976; Warner \& Jones, 1976; Brown, et al., 1979; Elner \& Campbell, 1981; Warner, et al., 1983; Abby-Kalio \& Warner, 1984; Seed, 1990; Lee \& Seed, 1992) have worked extensively on the biomechanics, morphology and anatomy of brachyuran chelae. In predatory forms, strong crushing forces often generated by the chela generally allow feeding on hard body organisms, particularly when applied through the occlusive surfaces (Warner \& Jones, 1976; Brown, et al., 1979; Elner \& Campbell, 1981; Blundon \& Kennedy, 1982; Abby-Kalio \& Warner, 1984). In portunid crabs the effeicency of the crushing process, crushing behavour and its effect on predation with respect to the cheliped ecology have been extensively reviewed (Ebling, et al., 1964; Elner, 1980; Seed, 1982; Jubb et al., 1983; Cunningham \& Hughes, 1984; Jensen \& Jensen, 1985; Davidson, 1986). The concept of the coevolution of cheliped size with hard-body prey in different regions was extensively reviewed by Vermeij, 1976; Abele et al., 1981). In heterochelous crabs such as Uca the size of the larger chela was considered to serve as a template in determining sexuality, thus reflecting the strong emphasis placed on mating needs as selective forces in chela evolution. (Elner, 1978). In the present study, we investigate the phenomenon of relative growth and its ecological role in ocypodid crabs with particular reference to the fiddler crab Uca tangeri.

\section{MATERIALS AND METHODS MORPHOMETRICS}

Twenty-five $0.25 \mathrm{~m}^{2}$ standard quadrat (Holmes \& Melntyre, 1984) samples were randomly taken alternately along transects running from low to high water levels during October, 1989. Crabs were extracted from their burrows each time, using a shovel and, the length and width of individual crab skeletal dimensions measured to the nearest $0.01 \mathrm{~mm}$ using an EHB venier calipers. A total of 1902 crabs comprising 925 males and 977 females were collected during the investigation. A wide range of sizes were collected for both sexes. Maximum carapace width, chela height, and position of the master chela (handedness) of both chelae were recorded for each crab. The mechanical advantage was calculated as the ratio of the distance ("a") from the point of attachment of closer apodeme (to the distance from pivot) lever length to tip ("b") of the dactylus (dactylus length) ("a"/"b") (Fig. 1). As the depth of the master chela (males) and the minor chela (females) as well as the mechanical advantage (grip strength) change with size (Abby-Kalio \& Warner, 1989), average values recorded for these parameters were measured only from crabs greater than $30 \mathrm{~mm}$ (range

I. Ewa-Oboho, School of Ocean Science \& Technology, Akwa Ibom State University, Ikot Akpaden, P. M. B. 1167, Uyo, Akwa Ibom State, Nigeria

N. Abby-Kalio, Department of Biological Sciences, River State University of Science and Technology, Port Harcourt, Rivers State, Nigeria 
30.5 to $40.5 \mathrm{~mm})$ carapace width $(\mathrm{CW})$ for males $(n=720)$. For females crabs with (CW) greater than $25 \mathrm{~mm}$ (range 25.5 to $34.2 \mathrm{~mm})(\mathrm{n}=902)$ were measured.

\section{USE OF CHELA IN REPRODUCTION}

The relationship between cheliped size and reproductive success was evaluated by comparing the distributions of chelal depth among crabs within mating pairs, with those obtained for the male crab population of similar size collected from the same locality. Mating pairs were collected throughout the reproductive season of 1989.

\section{ENERGY MAINTENANCE COST}

The basal metabolism of inactive crabs was estimated from measurements of oxygen consumption. All experimental crabs $(n=40)$ were starved for two days before they were used. This was to avoid changes in metabolic rate which may result from food ingested prior to the experiment (Wallace, 1973). The chelipeds of 10 individuals were removed and the crabs allowed to recover for 1 month before their metabolic rates were measured. Oxygen consumption rate was determined by monitoring the changes in dissolved oxygen. The respirometer was filled with oxygen-saturated saline $(30 \% \mathrm{o})$ filtered seawater and maintained at $26^{\circ} \mathrm{C}$. The water was stirred by the magnetic stirrer and the partial pressure of the dissolved oxygen monitored using a radiometer oxygen-pH analyser. All experimental crabs were allowed to settle in the respirometer for at least 1 hour before measurements were made and the change in partial pressure of oxygen was then monitored over a period of more than 1 hour. Preliminary experiments show that with or without the cheliped oxygen uptake by Uca was independent of oxygen concentration down to about $20 \%$ saturation.

\section{RESULTS}

\section{MORPHOMETRICS}

Male Uca tangeri is heterochelous. There was no significant difference $(P>0.01)$ in the handedness in the male crabs (Table 1). In males the major chela was just as likely to appear on the right $(50.5 \%)$ or left side $(49.50 \%)$. Sexual dimorphism in master chelal size, but not structure (occlusive geometry) is also evident. In sexually mature crabs, both the master chelal height and mechanical advantage at the dactylus tip are significantly $(p<0.05)$ greater amongst male crabs than amongst females of comparable carapace width (Table 1). The higher mechanical advantages of male crabs is due to the greater distance between the point of attachment of the flexor apodeme and the dactylar pivot (p), rather than to a shorter dactylus (Fig. 1), thus corresponding to the greater master chelal height observed in the males. The chelipeds in Uca tangeri account for about $25 \%$ of the total body fresh weight in males but less than $18 \%$ in females, where as the two minor chelae are similarly small in size and indistinguishable.

The change of gradient (at about $30 \mathrm{~mm} \mathrm{CW}$ ) in the regression between the master chelal height and carapace width in male Uca tangeri (Fig. 2a) is suggestive of a strong association of chelal size with sexual (reproductive) function. Significant differences were observed in gradients of regression lines for individuals greater or smaller than $30 \mathrm{~mm} \mathrm{CW}$ for male crabs (slope for individuals $>30 \mathrm{~mm} \mathrm{CW}=1.21$, for those $<30 \mathrm{~mm} \mathrm{CW}=1.7 ; \mathrm{P}<0.005$ ). The change in slope was not significantly evident in the female (Fig. 2b) individuals (slope for individual $>30 \mathrm{~mm} \mathrm{CW}=1.08$, for individuals $<30 \mathrm{~mm} \mathrm{CW}=1.05, \mathrm{P}>0.05$.

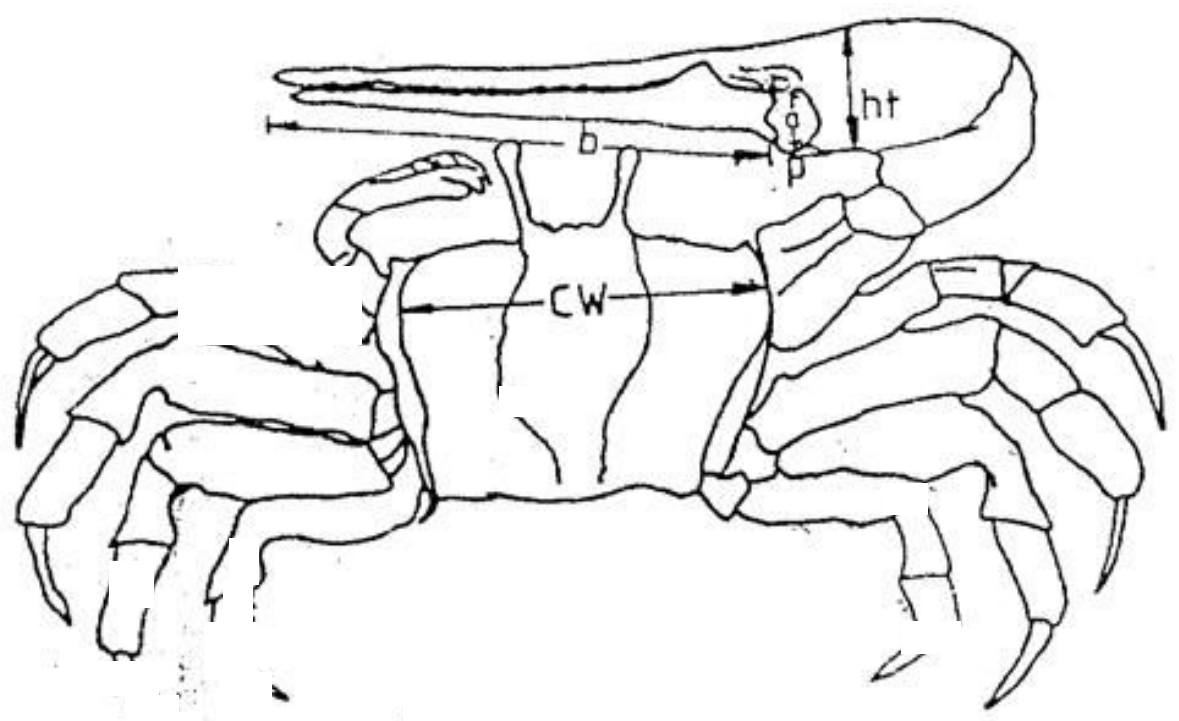

Fig. 1. Uca tangeri. Diagram showing the various morphometric features measured. Ht: chela height; $\mathrm{P}=$ pivot, $\mathrm{a}$ : distance from point of attachment of closer apodeme to pivot; $\mathrm{b}$ : distance from pivot to tip of dactylus. 




Fig. 2: Uca tangeri: Allometric relationship between master chelal height and carapace width in (a) male crabs (b) female crabs. 
Table1. Uca tangeri. Data on the morphometrics of chelipeds of Uca tangeri $\mathrm{MCH}$ : Master Chela Height; MCHMA: Master Chela Mechanical Advantage; CW: Carapace Width, BW: Body Weight; TOCHW: Total Cheliped Weight: \% RH: Right Handed;
$\%$ LH: Left Handed. All values are mean \pm SD. (Apart from handedness data obtained from individuals below $25 \mathrm{~mm} \mathrm{CW}$, all other data were obtained from sexually matured crabs (> $35 \mathrm{~mm} \mathrm{CW})$.

\begin{tabular}{lll}
\hline Morphometrics & \multicolumn{1}{c}{ MALE } & FEMALE \\
\hline MCH/CW & $0.0722 \pm 0.015$ & $0.025 \pm 0.01$ \\
MCHMA & $0.212 \pm 0.02$ (Master chela) & $0.082 \pm 0.020$ \\
TOCHW.BW & $0.142 \pm 0.022$ & $0.122 \pm 0.021$ \\
\% RH & 50.5 & $\begin{array}{l}\text { Because of their small and equal } \\
\text { \% LH }\end{array}$ \\
\hline
\end{tabular}

\section{USE IN REPRODUCTION}

Over $75 \%$ of the males in the 20 mating pairs of Uca tangeri collected in the intertidal zone of the Bonny estuary mud flat had master and small chelae which were above mean size when compared with values predicted by the regression equations, for the total male population (Figs. 3a and 3b). Analysis of covariance revealed that over the same size range significant difference in the size of both chelae exist between the mating male population and the total male population (for master chelae $F=9.628, P<0.005$; for smaller chelae $F=5.582, P>0.025)$. Males found in the mating pairs were not less than $40 \mathrm{~mm}$ CW. 

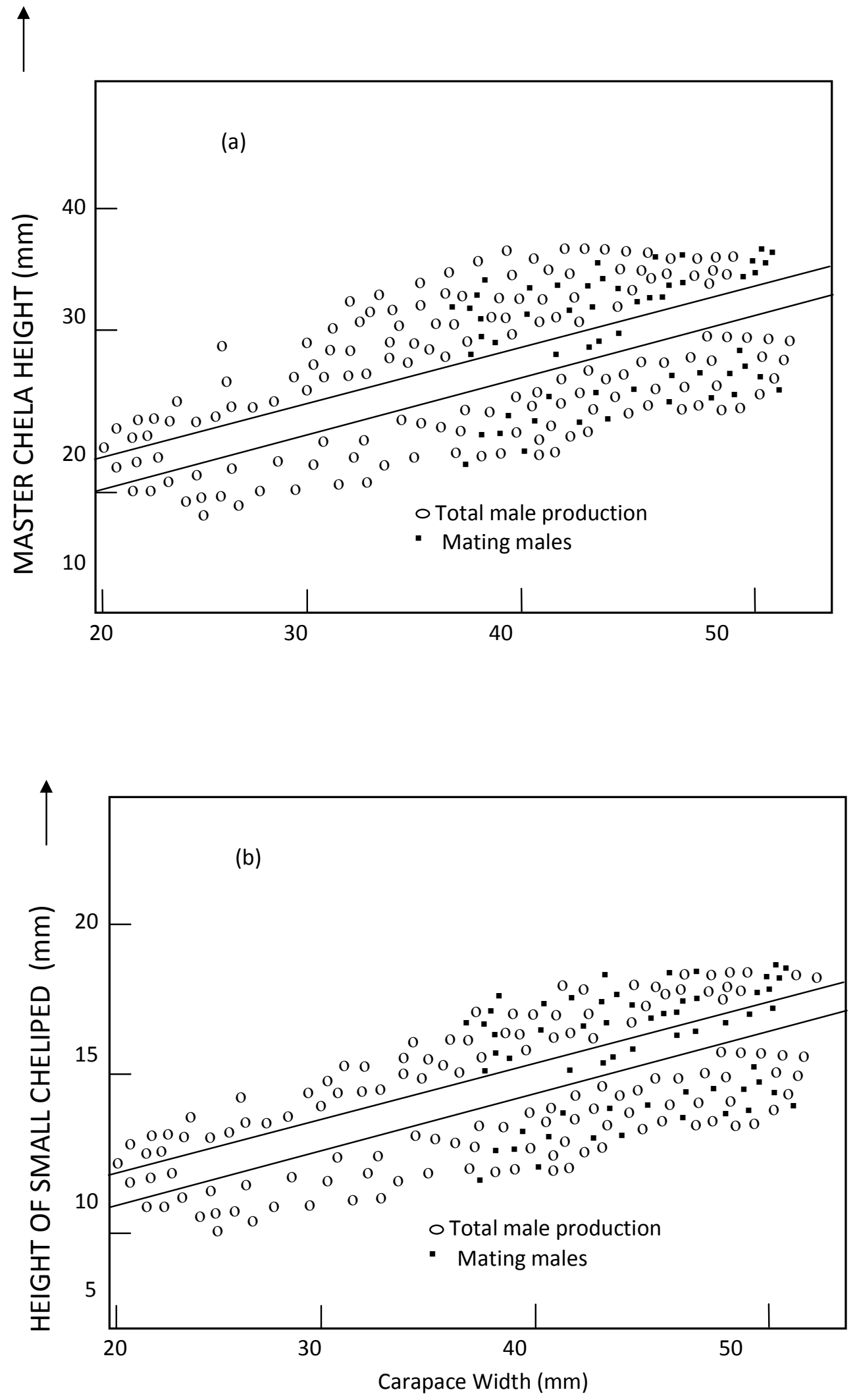

Fig. 3: Uca tangeri. Relationship between chelal size and carapace width for mating male crabs compared with those for total male population (a) Master chela (b) Smaller chelae 
ENERGY MAINTENANCE COST

The mean metabolic rate for resting Uca tangeri was $0.306 \pm 0.105 \mathrm{ml} \mathrm{O}_{2} \mathrm{~g}^{-1} \mathrm{~h}^{-1}$. The rate was independent of crab size $(r=0.231, P>0.1)$ for the regression between specific oxygen uptake rate and total body weight. The oxygen consumption rate could be predicted from dry weight alone, irrespective of the presence or absence of chelipeds or the proportion of total body dry weight that can be attributed to the cheliped (Fig. 4).

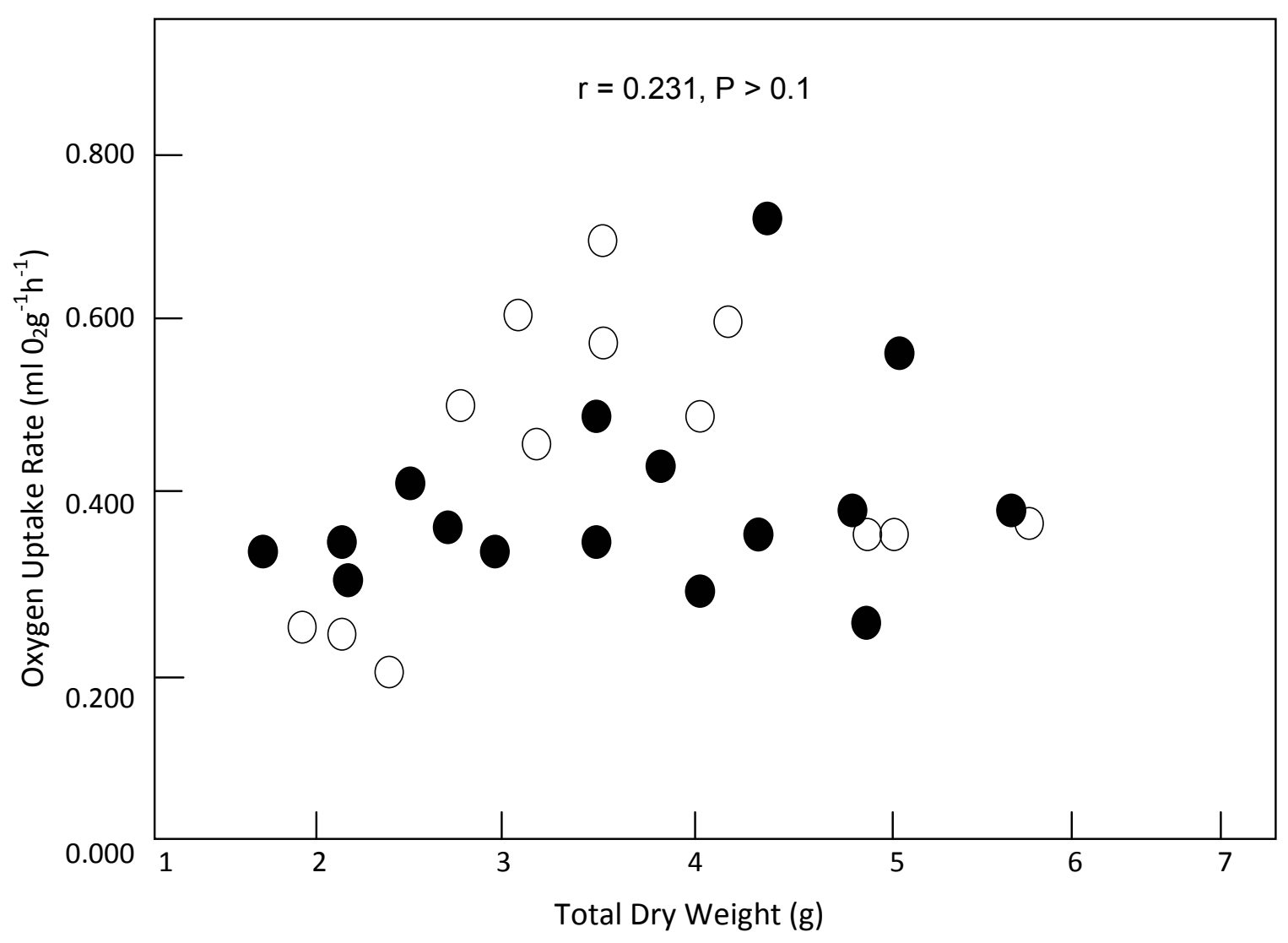

Fig. 4: Uca tangeri. Relationship between oxygen consumption rate and total body dry weight at $26^{\circ} \mathrm{C}$ ( ) represents normal in Oviduals ( ) represents individuals with ort chelipeds.

\section{DISCUSSION AND CONCLUSION}

The multi-functionality of enlarged chelae is determined probably by a variety of selective forces (Lee \& Seed, 1992). In order to fully understand the evolution of large size and structure, the fitness implication of all important characteristics of such a multifunctional structure is necessary. For most portunid crabs, studies have shown that among the diversity and seasonality in food items consumed, hard-body prey were often found in the natural diet (Paul, 1981; Williams, 1982; Davidson and Marsden, 1987). It therefore becomes questionable whether the cheliped, which in some portunids (e.g Carcinus maenas) account for greater than $30 \%$ of the total body weight (Lee \& Seed, 1992) evolved only in response to the selection pressure for obtaining an optimal diet consisting mostly of hard-bodies prey. In $U$. tangeri, the cheliped can account for more than $35 \%$ of the total body weight but the crab has a detritus-deposit feeding habit, where minute sediments are picked up with tips of the small chelae for sorting (Ewa-Oboho, 1993). This means that the enlarged master chela may not serve feeding function in $U$. tangeri.
Values obtained from measurements of the metabolic rates for $U$. tangeri chelipeds suggest that these structures impose on higher maintenance cost than other structures in the body, when oxygen uptake rate was measured from dry tissue weight. $A$ mean oxygen uptake rate of $0.306 \pm 0.105 \mathrm{ml} \mathrm{O}_{2} \mathrm{~g}^{-1} \mathrm{~h}^{-1}$ in the resting state was obtained. But since the chelipeds make up to $35 \%$ of the total body weight in $U$. tangeri appropriately the same proportion of energy is assumed to be spent on their maintenance. In Liocarcinus holsaitus however, enlarged chelipeds could result in higher metabolic rates particularly during periods of active swimming (Lee \& Seed, 1992). This may explain the negatively allometric relationship between cheliped size and carapace width reported for swimming crabs (Davison and Marsden, 1987).

The master chela in $U$. tangeri plays important role in mating competition and sexual selection which perhaps is one major driving force in the evolution of large chelae (Stein, 1976). In his review of the visual display in cheliped in brachyuran crabs, Wright (1968) concluded that cheliped movements constitute a 
principal component in the expression of aggressiveness apart from its role in intraspecific encounters (Warner, 1967; Ewa-Oboho, 2006).

The role of the cheliped in reproduction (mating) is supported by the findings of the present study. In $U$. tangeri courtship occurs at high densities in the Bonny estuarine mudflats and this may lead to intense competition among male and females. It was observed that through fights and aggression, mating pairs were formed. Only males which are strong enough to defend the females can reproduce successfully. Fighting behavior is therefore an effective intersexual selection force. It is not surprising, therefore, that the chelae, as the principal structure used for expression of aggressiveness, is significantly larger in successful males in the mating population. Besides, chelae in $U$. tangeri are in general larger amongst males than females. The growth patterns of the chelipeds also provide strong evidence that the evolution of massive chelae in Uca crabs is controlled by sexual selection. Significant changes in the allometry of various dimensions, including the chela, at sexual maturity was also very obvious in Uca tangeri, suggestive of a sexual function in this crab. The smaller chela in females could be ascribed to the larger amount of energy invested in the production of gemetes. Clutch sizes can be in the order close to $10^{6}$, (Warner, 1977).

That sexual selection is a major driving force controlling sexual dimorphism in cheliped size is evident from the markedly different roles of the two sizes of the chelipeds seen during combat and display courtship, where cheliped are the main organ of aggression in inter-male conflicts (Hartnoll, 1978; Lee \& Seed, 1992). The maintenance of such a costly organ particularly during non reproductive periods in males goes to suggest that the size of the female chelae is close to the energetic survival optimum. Using various chelae size to body ratios, results of experiments shows the role of chelae in agonistic interactions, such as competition for food and shelter. Sinclair, 1977; 0'Neill \& Cobb 1978; Glass \& Huntinford, 1998, suggested that the relative size of individual crab was important in predicting the outcome of a fight. They demonstrated that smaller crabs could win the fights involving crabs of similar size. Such deviation could be explained if the natural variability in the chelal size to carapace width ratio is taken into consideration.

\section{REFERENCES}

Abby-Kalio, N. J. and Warner, G. F., 1984. Effects of two different feeding regimes on the chela closer muscles of the shore crab Carcinus maenas (L). Mar. Behav. Physiol. 11:209-218.

Abele, L. G., Heck, K. L. Jr., Simberloff, D. S. and Vermeij, G. J., 1981. Biogeography of crab claw size: assumptions and a null hypothesis. Syst. Zool. 30:406-424.

Blundon, J. A. and Kennedy, V. S., 1982. Mechanical and behavioural aspect of blur crab Callinectes sapidus (Rathbun), predation on Chesapeake Bay bivalves. J. Exp. Mar. Biol. Ecol. 165:47-65.
Brown, S. C., Cassuto, S. R. and Loos, R. W., 1979. Biomechanics of chelipeds in some decapods crustaceans. J. Zool. Lond. 188:143-159.

Campbell, A., 1981. Force, function and mechanical advantage in the chelae of the American lobster Homarus americanus (Decapoda: crustacean). J. Zool. Lond. 193:269-286.

Champman, D., Hawkey, N. and Waring, D., 1982. Structure and function of the chelae and chela closer muscles of the shore crab Carcinus maenas (Crustacea: Brachyura) J. Zool. Lond. 196:431-438.

Cott, H. B., 1929. Observations on the natural history of the racing-crab ocypode Ceratophtha lina from Beira Proc. Zool. Soc. London 1929 (4): 755765.

Cunniingham, P. N. and Hughes, R. N., 1984. Learning of predatory skills by shorecrabs Carcinus maenas feeding on mussels and doy whelks. Mar. Ecol. Prog. Ser. 16:21-26.

Davidson, R. J. and Marsden, I. D., 1987. Size relationship and relative growth in New Zealand swimming crab Ovalipes catharus white, 1843. J. Crust. Biol. 7:308-317.

Ebling, F. J., Kitching, J. A., Muntz, L. and Taylor, C. M., 1964. The ecology of Lough Inc. XIII. Experimental observations of the destruction of Mytilus edulis and Nucella lapillus by crabs. J. Amin. Ecol. 33:73-82.

Elner, R. W., 1980. The influence of temperature, sex and chela size in the foraging strategy of the shore crab, Carcinus maenas (L.) Mar. Behav. Physiol. 7:15-24.

Ewa-Oboho, O. I., 1993. Substratum preference of the tropical esturine crabs; Uca tangeri Eydoux (Ocypodiadae) and Ocypode cursor (L.) Ocypodidae. Hydrobiologia 271:199-127.

Ewa-Oboho, O. I., 2006. Theoretical basis of allometric Relationship in juverile Brachyri: Data from a West African Mangrove swamp crab population. West African Journal of Applied Ecology Vol. 10 35-45.

Hamilton, P. V., Wishimoto, R. T. and Halusky, J. G., 1976. Cheliped laterality in Callinectes sapidus (Crustacea: Portunidae). Biol. Bull. 150:393410.

Hartnoll, R. G., 1974. Variation in growth pattern between some secondary sexual characters in crabs (Decapoda: brachyuran). Crustaceana 27:131-136.

Herreid, C. F., 1976. Skeletal measurements and growth of the crab Cardisoma guanhiur Latreille. Crustaceana 13: 39-44. 
Holme, N. A. and Mcntyre, A. D., 1984. Methods for the study of marine benthos. $2^{\text {nd }}$ Edition. IBP Hard Book 16 Blackwell Scientific Publications.

Hughes, R. N., 1989. Foraging behavior of a tropical crab: Oziuz verreauxii. Proc. R. Soc. Lond. Ser. B. 237: 201-212.

Jensen, K. T. and Jensen, J. N., 1985. The importance of some epibenthic predators on the density of juvenile benthic macrofauna in the Danish Wadden Sea. J. Exp. Mar. Biol. Ecol. 89: 157174.

Jones, A. R., 1976. Leverage and muscle type in crab chelae (Crustacea: Brachyura) J. Zool. Kond. 180:57-68.

Lee, S. Y. and Seed, R., 1992. Ecological implications of chelipe size in crabs: Data from Carcinus maenas and Liocarcinus holsatus. Mar. Ecol. Prog. Ser. 84: 151-160.

O'Neill, D. J. and Cobb, J. S., 1979. Some factors influencing the outcome of shelter competition in lobster (Hmoarus americanus). Mar. Behav. Physiol. 6: 33-45.

Paul, R. K. G., 1981. Nature diet, feeding and predatory activity of the crabs Callinectes arcuatus and $C$. toxotes (Decapoda. Brachyura. Portunidae). Mar. Ecol. Prog. Ser. 6: 91-99.

Seed, R., 1990. Morphology, occlusive geometry and mechanical advantage in the chelae of Thalamita danae Stimpson and $T$. crenata Latreille (Decapoda: Portunidae) from Hong Kong. In: Morton B. (ed) Proc. Of the Second Inter. Biol. Workshop: the marine flora and fauna of Hong Kong and Southern China.

Sinclair, M. E., 1977. Agonistic behavior of the stone crab Menippe mercenaria (Say) Amin. Bahv. 25:193-207.
Stein, R. A., 1976. Sexual dimorphism in crayfish chelae, functional significance linked to reproductive activities. Can. J. Zool. 54:220-227.

Warner, G. F., 1969. The Occurrence and distribution of crabs in a Jamaican mangrove swamp. J. Anim. Ecol. 38, 379-389.

Warner, G. F., 1977. The biology of crabs. Elek Science, London.

Williams, M. J., 1982. Natural food and feeding in the commercial sand crab Portunus pelagicus (L.) (Crustacea: Decapoda Portunidae) in Moreton Bay Queensland. J. Exp. Mar. Biol. Ecol. 59:165-176.

Wright, H. I., 1968. Visual displays in brachyuran crabs: field and laboratory studies. Am. Zool. 8: 655665.

\section{CAPTION ON FIGURES}

Fig. 1: Uca tangeri. Diagram showing the various morphometric features measured. Ht: chela; height. $\mathrm{P}=$ pivot, $\mathrm{a}$ : distance from point of attachment of closer apodeme (c) to pivot; b: distance from pivot to tip of dactylus.

Fig. 2. Uca tangeri. Allometric relationship between master chelal height and carapace width in (a) male and (b) female crabs.

Fig. 3. Uca tangeri. Relationship between chelal size and carapace width for mating male crab compared with those for the total male population (a) Master chelae, (b) smaller chelae.

Fig. 4: Uca tangeri .Relationship between oxygen consumption rate and total body dry weight at $26^{\circ} \mathrm{C}$; normal individuals; (0) individuals without chelipeds. 
